\title{
A STUDY OF THE ENGLISH TEXTBOOKS FOR SENIOR HIGH SCHOOL IN FOUR ENGLISH SKILLS ON GENDER EQUALITY IN SERANG CITY - BANTEN
}

\author{
Nurhaedah Gailea*, Yumna Rasyid ${ }^{* *}$ \\ Universitas Sultan Ageng Tirtayasa, Indonesia* \\ Language Teaching/Applied Linguistics Study Program of Graduate Program of \\ Universitas Negeri Jakarta, Indonesia** \\ Ida_gailea@yahoo.co.id* \\ yumzai.rasyid@gmail.com**
}

\begin{abstract}
The objective of the research is to find out deeply the aspects of equal gender on English textbooks for Senior High School by Indonesian and English writer in Serang City. The method used in this research is qualitative research with content analysis technique.The data collected through document review. The research finding shows that the perecentage of men are higher than women in the aspects of main character and historical event, the use of equal language, public and domestic role, and art talent, sport, and intellectual competence on the books of indonesia writer in four language skills such as listening, speaking, reading, and writing.This description shows that women are inferior because of culture, misinterpretation of religion, and patriarchy system factor. Whreas the perecentage of men and women are gender equal on the book of English writer, especially in the main character, the language equal, the public and domestic role, and the art talent, but the sport and intelectual competence showed that the perencentage of men are high. It means that women have opportunity as men and especially domestic role is responsibility of both men and women. It can be concluded that the Englsh textbook is written by Indonesian that called curriculum 2013 can not be used as English lesson, whereas the English textbook of English writer can recommend as English lesson because it found the equal gender.
\end{abstract}

Keywords: gender equal, curriculum 2013, English textbook, Indonesian writer, English writer.

There are so many media can be used to help teachers and students in teaching and learning process. One of the influential media in teaching and learning process is textbook. According to Riazi (2003: 52), a textbook used in the English Foreign Learning classroom plays crucial roles in language teaching and learning process because it can help teacher to provide various learning materials especially for English language learning. Related to this explanation, it expected that the textbooks of curriculum 2013 had used gender equality in developing the English materials. Kemp (2011: 217) explains that textbook has its own potential to be used as a tool to undermine gender equality.

In order to adjust those global challenges, Indonesia government through Depertemen Pendidikan Nasional tries to respon several problems, such as issues on democracy, human right, and gender through curriculum reform. The problems have been accommodated in the 2004 curriculum, which is known as Competence Based Curriculum. Additionally, Depniknas in the formulation of the basic framework of the curriculum, stated that the learning material should cover cultural competence, to enchance the students to put themselves as good as possible in the cultural system and pluralistic society value arrangement. 
Nowdays most of English textbooks only focus on language it selft. It is really rare that textbook concerns with global issues expecially gender equality which represents balanced relationship between female and male. According to Hamdan (2010:1), school textbooks play a crucial role in determining pupils' worldview of female and male role in society. Futhermore, Cunningsworth (1995; 7), concluded roles of textbooks; as a presented material, as a sources of classroom activities, as a source of gramma, vocabularies, intonation for students, as a syllabus. Therefore, a textbook should cover all aspects of learning: stated and/ or hidden curriculum. Gender issue in Education can be affected by materials used in teaching and learning activities. In order to promote gender equality, English textbooks are expected to be neutral.

The gender equal in education also included students' experience. The experience of man and woman while they are learning in the classroom. Releted to this, a teacher, textbook, the environment of learning and result of learning should treat the equal right between men and women in learning activities. According to Prastowo (2013:175-6), the standard present the materials in textbook should pay attention the equal right or gender egual and also care the environment of learning. Furthermore, Griffiths (2008: 75) explains that gender socialization is a key factor in any relative success that women of any age have in language learning, and it seems clear that the language learning success is caused by a combination of nature and nurture.

Based on the expalanations above, the researcher tried to conduct this reseach because there are some guestions from the students of English Departement of Untirta University that the English textbooks of Senior High Shool still find gender bias in the materials, for example talking about profession; 'businessman', and also she as a member of Woman Study of Untirta University has to do the research that related to the gender equal in textbooks, especially English textbooks to get the important information about it in education. And the important point here is to know whether it finds the gender equality in the English textbooks that is written by Indonesian and English writer of Senior High School in Serang City that used curriculum 2013 based on four English skills: listening, speaking, reading and writing.

The main focus of the research is to analyze and to find out the meaning of gender equal aspects deeply in English textbooks for Senior High School by Indonesian and English writer based on four english skills in Serang City- Banten province. There are five sub-focus of gender equality which analyzed in the English textbooks. Firstly, visibility of female and male which focus on the main charater, and the historical events and developments based on four English skills. Secondly, linguistic Equal which focus on generic use of she and he, and use of male/female refers one's profession based on four English skills. Thirdly, gender role and behaviors which focus on public and domestic role based on four English skills. Fourth, equal gender between female and male which focus on art talent, sport ability, and intelectual competence in art and sport based on four English skills. The last, it analyzed and find out equal gender deeply by Indonesian and English writer whether the English textbooks conform to standard the equal gender aspects to use as English lesson at Senior High School in Serang City. 


\section{METHOD}

The method used in this research is qualitative research method with content analysis technique. Research using qualitative content analysis focus on the characteristics of language as communication with attention to the content or contextual meaning of the text. The text data can be categorized print media such as articles, books or manual, and this research used English textbooks as data to analyze the aspects of equal gender which found in these books. According to Neuendorf (2002:15), content analysis is as indepth analysis using quantitative or qualitative technique of messages using a scientific method and is not limited as to the types of variables that may be measured. Furthermore, Wahyuni said that the goal of content analysis is to provide knowledge and understanding of the phenomenon under study (2012; 122). Thus, content analysis is a research method for the subjective interpretation of the content of the text data through the systematic clasification process of coding and identifying themes or patterns.

The data in this research are four English Textbooks for Senior High School Grade X of curriculum 2013 in Serang City. The English textbooks are written by Indonesian that are Pathway To English for Senior High School Grade X General and Interested Program, and English language SMA Kelas X curriculum and book centre, Balitbang, Kemdikbud. Whereas the title of the English textbook writer is Real English for Senior High School Grade X.

Related to the qualitative research, the procedure in collecting data, analysis, and interpretation can go simultaneously. And the instrument of the research is the researcher herself who helped by using the critical gender sheets as follow:

Table 1. Critical Gender

\begin{tabular}{|c|c|c|c|c|c|c|}
\hline No & Category & Book 1 & Book 2 & Book 3 & Book 4 & Total \\
\hline A & $\begin{array}{l}\text { Visibilty Of Female and } \\
\text { Male }\end{array}$ & $\%$ & $\%$ & $\%$ & $\%$ & $\%$ \\
\hline 1 & $\mathrm{~F}$ as main character & & & & & \\
\hline 2 & M as main character & & & & & \\
\hline 3 & $\begin{array}{l}\text { F in historical events and } \\
\text { developments }\end{array}$ & & & & & \\
\hline 4 & $\begin{array}{l}\mathrm{M} \text { in historical events and } \\
\text { developments }\end{array}$ & & & & & \\
\hline B & Equal in Linguistic & $\%$ & $\%$ & $\%$ & $\%$ & $\%$ \\
\hline 1 & $\begin{array}{l}\text { Generic use of "she", } \\
\text { "woman" to refer person of } \\
\text { people }\end{array}$ & & & & & \\
\hline 2 & $\begin{array}{l}\text { Generic use of "he”, “man” } \\
\text { to refer person of people }\end{array}$ & & & & & \\
\hline 3 & $\begin{array}{l}\text { Use of “woman”, "lady” or } \\
\text { female gender word forms } \\
\text { to refer one's profession }\end{array}$ & & & & & \\
\hline 4 & $\begin{array}{l}\text { Use of "man", "male" to } \\
\text { refer one’s profession }\end{array}$ & & & & & \\
\hline $\mathbf{C}$ & $\begin{array}{l}\text { Strerotyped/ Equal in } \\
\text { Gender Roles and } \\
\text { Behaviors }\end{array}$ & $\%$ & $\%$ & $\%$ & $\%$ & $\%$ \\
\hline 1 & F work outside home & & & & & \\
\hline
\end{tabular}




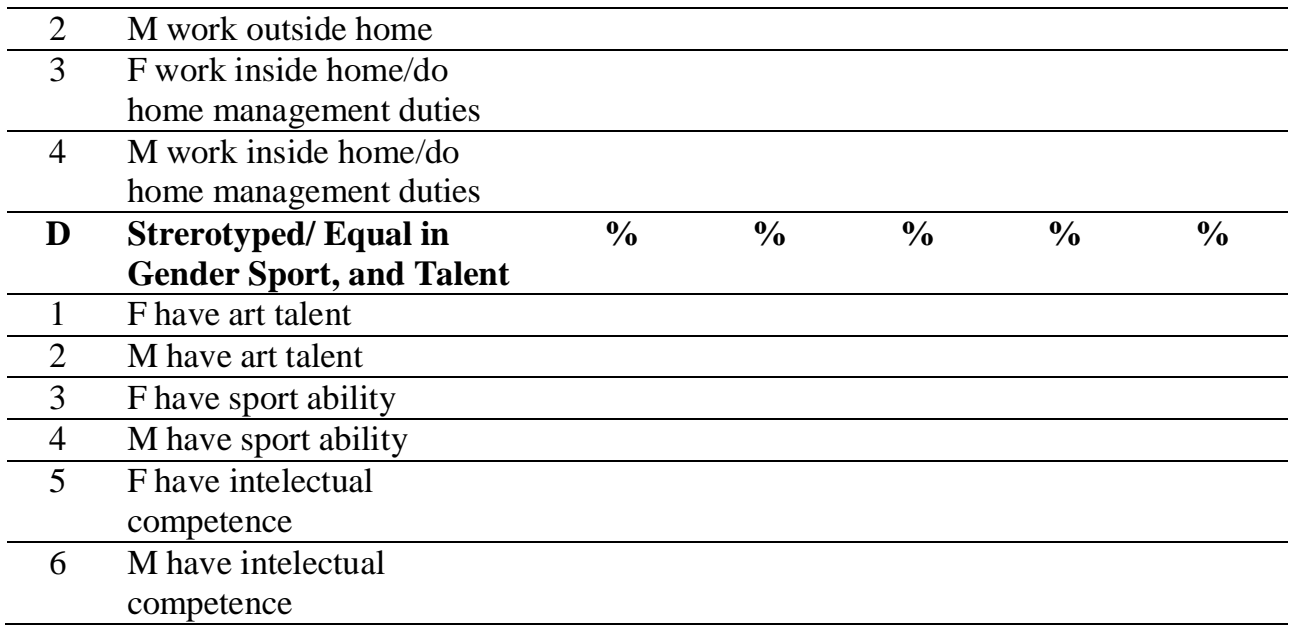

The critical gender sheets above, it helped the researcher to analyze the materials of English textbooks which related to gender equality that are visibility of Female and Male, Equal in Linguistic, Equal in Gender Roles and Behaviour, and Egual in Gender Sport and Talent. After analysis the aspects of gender equality, it found out how the Indonesia and the English writer presented the materials of English lesson related to gender equality and also found out the meaning deeply of Indonesia and English treatment toward man and women in social life.

\section{RESULTS AND DISCUSSION}

Based on calculating the data of research, it can be interpreted five important points that is how the writers of textbooks presented the gender equality in these books. They are the analysis of main character and historical development, the analysis of using linguistic equal, the analysis of gender role and behaviour, and the analysis of gender sport and art talent.

\section{A. The analysis of gender equality on the main character and the historical development in the textbooks of the four English skills.}

Based on the data calculating of textbooks, it showed that the main character of female is $50 \%$ and male is $50 \%$, and the historical development showed that female is $34,38 \%$ and male is $65,62 \%$. It means that the aspect of main character is neutral because the materials of listening, speaking and writng presented light materials, for example the dialogue of daily activities. Whereas the development of historical showed male dominated in the materials of reading such us; talking about hero and scientist.

The above description showed that women still faced dicrimination in the English materials because of culture factor, especially patriarchy syestem. And it has mentioned before that the long time ago women were not appropriate to place in a story or to act in a play becuase it is regarded taboo. After feminist struggled to get the equal right women have given opportunity as supporting charater or as a partner of men in action story. Whereas men dominated in reading subjects because it regarded that they are clever or more qualified tham women. 


\section{B. The anlysis of gender equality on the use sexism language in the textbooks of the four English skills}

Based on the data analysis of the textbooks, it showed the use third person refer to people; female (she) is $46,04 \%$ and male (he) is $53.96 \%$. the factor of use third person refer to profession showed that female is 33,33\% and male is $66,67 \%$. The next factor of the use third person of mention before showed that female is $26 \%$ and male is $74 \%$. It means that female still found the gender inequality, especially in the writing skill.

Related to the explanation above, it can be concluded that male dominated th use of sexisme language. It means that in the society life, it still find the gender role division so that it arose the gender bias in the use of sexism language. This situation described woman as the second class because it presented terms or words such as businessman, chairman and etcerera. Therefore it is better to intrduce to students the neutral language, for example chair person (some experts’ sugestion).

\section{The analysis of gender equality on domestic and public role in the textbooks of the four English skill}

Based on the data calculating, it showed that the domestic role is found $80 \%$ for female and $20 \%$ for male. Whereas the public role is found $36,36 \%$ for female and $63,64 \%$ for male. It means that the domestic role is dominated women, whereas the public role is dominated male. Some experts explained that this problem is caused cultural factor; from earliest childhood, females were trained to assume domestic responsibilities, and it is explained by sociologist; girls played at keeping house, dressing dolls, and cooking food. Girls were urged to sew and cook, boys to buld club houses and thinker automobiles. And it is regarded that women are feminine so they are appropriate to do domestic role whereas men are masculine so they are appropriate to do public role. If women work public sector, they get the job such as secretary, teacher, receptionist, and nurse. Whereas men are explained as a pilot, a business person, doctor, president, and manager.

Related to the view above, Feminist Liberal and Moslem Feminist did not agree that the domestic role is the responsibility of women but this is the responsibility of both women and men. And they said that in Globalzation era, it is important way that it does no depend on norms which considered gender more.

\section{The analysis of the gender equality on art talent, sport, and intelectual competency in the textbooks based on four English skills}

Based on the data calculating, it showed female is 53,85\%, and male is $46,15 \%$ on the art telent aspect. And the next aspect is sport to show female is $12,05 \%$, whereas male got the highest score is $87,05 \%$ than female in the reading materials, and the aspect of intelectual competency; female is $35,71 \%$, and male is $64,29 \%$. It means that in the art talent aspect female got the highest score than male because it has mentioned before, female is feminine and she is persented in the materials, for example a singers, a dancers, a beauty specialist and an artist, whereas male is masculine so that his talent is a technician, a financial expert, contractor and scientist.

The gender equality aspect in the sport and also the intelectual competency showed that male got score is highest than female. The problem of description above, it is explained that female has limitation physical or weak and she gets many negative stereotype, for example, irrational, emotional, sensitive and fainthearted person, 
whereas female gets a few positive stereotype, for example, soft, cooperative, and careful person. Whereas male gets more positive stereotype than female. They are a strong person, rational, independent, active, domination, ambitious, analytical, and courageous person, but he gets onlu a few negative stereotype that are improper and rudeness person. It can be concluded that the stereotype factor influenced male to dominate the sport and the intellectual competency.

\section{E. The analysis of gender equality in the textbooks of four English skills by Indonesian and English writer}

Based on the result of analysis data, it showed that the English textbooks are written by Indonesian; Pathway To English for Senior High School Grade X General Program’ (book 1), 'Pathway To English for Senior High School Grade X Interested Program' (book 2) by Sudarwati and Grace, and 'Bahasa Inggris SMA Kelas X (buku 3) by Bookmaking Curriculum Center, Balitbang, Kemdikbud still presented gender inequality in the material of listening, speaking, writing, and reading.

Related to the explanation above, the factor of historical development, sport and intellectual competency still found male who dominated these factors because one of factors influenced that is the positive stereotyped of male. Besides that in the domestic role, it still showed that female dominated it. It means that Indonesian culture still strong to place women in this role althogh Moslem Feminist struggled hard to get equal right that is the domestic role is not only the responsibility of female but it is also male.

The English textbook is Real English for Senior High School Grade X by Peter James as English writer is found the gender equality aspect in materials of listening, speaking, writing, and reading. The reading materials related to the aspect of sport and intellectual competency to show female and male whose the equal right is in sport. It explained team football of girls and they can play the ball professionally. And the aspect of domestic role is explained the gender equal in the reading material and also presented picture in speaking material. It explained that the domestic role is responsibility of both male and female, and it is explained that the past, a woman's role was often to stay at home and take care of the childrend and the house work, but now, many women have their own career outside the home.

\section{CONCLUSION}

Based on the result of the research, it can be concluded that the textbooks of Indonesian writer can not be used as English lesson at Senior High School Grade X because it still find the gender inequality. Whereas the textbook of English writer can be used as English lesson because the writer payed attention the gender equal in presenting the materials of English skills.

\section{REFERENCES}

Andi Prastowo. 2013. Panduan Kreatif Membuat Bahan Ajar Inovatif. Jogyakarta,: Diva Press. 
Cunningsworth. 1995. A. Choosing Your Coursebook, Oxford: Heinemann.

Griffiths Carol. 2008. Lessons from Good Language Learners, New York: Cambridge University Press.

Hamdan, Sameer. 2110. English Language Textbooks Reflect Gender Bias: A Case Study In Jordan; Advance in Gender and Education.

James Peter. 2006. Real English for Senior High School Grade X: Jakarta ESIS Press.

Kimberly A. Neuendorf. 2002. The Content Analysis Guidedbook, London: International Educational and Professional Publisher.

Kemp, Nicholas. 2014. A Gender Analysis of The ESL Textbook Side by side. 2011. Retrieved May 15, from http://www.niit.ac.jp/lib/../14.

Kementerian Pendidikan dan Kebudayaan. 2014. Bahasa Inggris SMA Kelas X, Jakarta: Pusat Kurikulum dan Pembukuan, Balitbang, Kemdikbud.

Riazi, A. M. 2003. 'What Textbook Evaluation Schemes Tell Us? A Study of Textbool Evaluation Schemes of Three Decades'. In W. A. Renanda. (Ed), Methodology and Materials Design in Language Teaching. Singapore: SEAMEO Regional Center.

Sudarwati Th.M. and Grace Eudia. 2014. Patway TO English General and Interested Program, Jakarta: Erlangga.

Wahyuni Sari. 2012. Qualitative Research Method; Theory And Practice, Jakarta: Salemba Empat, 
International Journal of Language Education and Culture Review 